\title{
Mega-Events and Tourism: The Case of Brazil
}

By

\author{
Robert Baumann and Victor Matheson
}

August 2017

\section{COLLEGE OF THE HOLY CROSS, DEPARTMENT OF ECONOMICS FACULTY RESEARCH SERIES, PAPER NO. 17-03*}

\author{
Department of Economics and Accounting \\ College of the Holy Cross \\ Box 45A \\ Worcester, Massachusetts 01610 \\ (508) 793-3362 (phone)
}

(508) 793-3708 (fax)

https://www.holycross.edu/academics/programs/economics-and-accounting

*All papers in the Holy Cross Working Paper Series should be considered draft versions subject to future revision. Comments and suggestions are welcome. 


\title{
Mega-Events and Tourism: The Case of Brazil
}

\author{
By \\ Robert Baumann ${ }^{\dagger}$ \\ College of the Holy Cross \\ and \\ Victor Matheson $^{\dagger \dagger}$ \\ College of the Holy Cross
}

August 2017

\begin{abstract}
Mega-sporting events such as the FIFA World Cup are expensive affairs. Host countries often justify the spending required to stage these events by predicting that mega-events will draw large numbers of tourists. This paper analyzes monthly foreign tourist arrivals into Brazil between 2003 and 2015 and finds that the 2014 FIFA World Cup increased foreign tourism by roughly one million visitors. This number far exceeded expectations, but we show that roughly a quarter of this increase in foreign tourism was caused by the fortuitous advancement of Argentina's national team, and potential hosts should not count on the event to consistently produce out-sized tourism figures We conclude that on-field results can greatly influence FIFA World Cup tourism.
\end{abstract}

JEL Classification Codes: L83, Z23, F14

Keywords: World Cup, sports, tourism, Brazil, soccer

${ }^{\dagger}$ Department of Economics, Box 192A, College of the Holy Cross, Worcester, MA 01610 USA, 508-793-3879 (phone), rbaumann@holycross.edu

${ }^{\dagger}$ Department of Economics, Box 157A, College of the Holy Cross, Worcester, MA 01610-2395, 508-793-2649 (phone), 508-793-3710 (fax), vmatheso@holycross.edu 


\section{Introduction}

Major international sporting events are considered valuable prizes by many countries, and the competition to host these events can be vigorous. In order to justify the costs of hosting, it is often claimed that these events attract large numbers of well-heeled foreign visitors and can be engines of economic growth after the event. The 2014 FIFA (Fédération Internationale de Football Association) World Cup is no exception. Leading up to the event, the Brazilian Ministry of Sports forecasted the event would be worth no less than $\$ 70$ billion and attract 600,000 tourists to Brazil. ${ }^{1}$ Such claims were probably necessary to justify the extraordinary expense to host the event. The Brazilian Ministry of Sports reported stadium construction cost $\$ 3.6$ billion. $^{2}$ FIFA concedes that the overall cost of the event was \$15 billion, though the organization contributed $\$ 2$ billion towards operational costs. ${ }^{3}$

Unfortunately hosting decisions must be made on ex ante predictions of economic impact, which have a significant amount of variation and can be manipulated by those in favor of hosting. For example, the consulting firm Grant Thornton South Africa initially predicted 483,000 international visitors for the 2010 FIFA World Cup in South Africa. The firm revised their figures downward multiple times, once to "a gross economic impact of \$12 billion to the country’s economy” with 373,000 international visitors (Voigt, 2011), and then subsequently placing the economic impact at $\$ 7.5$ billion along with 198,400 annual jobs (Rihlamvu, 2011). Following the event, a report suggested “309,554 foreign tourists arrived in South Africa for the

1 Rapoza, Kenneth, “FIFA World Cup Forecast To Add \$70 Billion To Brazil's Economy”, Forbes, July 82011. 2 Manfred, Tony, “What Brazil's Brand-New \$3.6-Billion World Cup Stadiums Look Like”, Business Insider, June 92014.

3 FIFA, "FAQ: Setting the Record Straight", http://www.fifa.com/mm/document/tournament/competition/02/36/32/63/faq_en_neutral.pdf , accessed March 16 2017. 
primary purpose of attending the 2010 FIFA World Cup” and spent 3.64 billion rand (roughly $\$ 500$ million using contemporaneous exchange rates) during their stay (FIFA, 2010). While ex ante predictions can be useful, ex post economic impact estimates for similar events should also be considered. This is perhaps more vital in recent years as FIFA World Cups and Olympiads have been held in developing countries hoping to use the event to spur economic growth, e.g. Brazil (2014 FIFA World Cup, 2016 Summer Olympics), South Africa (2010 FIFA World Cup), and Russia (2012 Winter Olympics, 2018 FIFA World Cup).

This paper has two contributions. First, we estimate the net impact of the 2014 FIFA World Cup on foreign tourism into Brazil. Using monthly tourist arrival data from 2003 to 2015, we estimate the 2014 FIFA World Cup increased foreign visitors to Brazil by about one million people, which is significantly higher than government expectations of 600,000 prior to the event. Second, we identify a substantial source of variation to any ex ante economic impact prediction of the FIFA World Cup: on-field results. The FIFA World Cup finals begin with 32 teams, each of which is guaranteed three games during the "group stage" of the tournament. The outcomes of the group stage leave 16 teams in the "knockout round", which comprises of single elimination games. In terms of foreign tourism, the best scenario for the host country is that a nearby competitor will advance deep into the knockout round, which will attract its fans to the host country. Fortunately for Brazil, this is precisely what happened in 2014. Argentina, a populous country that shares a border with Brazil, saw its national team advance to the final game of the 2014 FIFA World Cup. We estimate this exogenous, on-field result had an enormous impact on foreign tourism into Brazil, particularly in July 2014 when Argentinians comprised over 80 percent of the net increase in foreign tourism. Supposing instead that Argentine national team was eliminated during its quarterfinal game to Belgium on July 5, 2014, we estimate that roughly 
250,000 fewer foreign tourists would have entered Brazil during the FIFA World Cup. In essence, the advancement of the Argentine national team contributed roughly one-quarter of the net increase in foreign tourists attributed to the FIFA World Cup. We conclude that on-field results greatly influence the net increase in tourism and therefore the potential economic impact, which means any ex ante prediction of an economic payoff from the FIFA World Cup is subject to a considerable amount of uncertainty completely out of the control of the event organizers.

\section{Impact Analysis}

Organizers routinely claim that sporting events have a large impact on host economies through the direct spending of tourists, and the FIFA World Cup is no exception. According to the consulting firm Deloitte, the 2007 Rugby World Cup attracted over 350,000 overseas visitors to France, while the event "can deliver between £260m and £1.1 billion of Gross Value Added to a Host Nation, depending on location” (Deloitte, 2008). The United Kingdom’s (UK)

Department of Transport expected 500,000 tourists and 70,000 athletes and officials for the 2012 Summer Olympics in London, an increase of 260,000 visitors over a typical summer month (The Week, 2012). Early predictions for the 2016 Summer Olympics in Rio de Janeiro suggested the event would bring an additional 480,000 tourists, with "experts believ[ing] this number could be surpassed” (Utley, 2014).

Impressive tourism predictions are not limited to weeks-long tournaments such as FIFA World Cups or the Olympiads. Some tourism estimates for the 2005 National Basketball Association All-Star Game were as high as 100,000, even though the event was held in arena that has less than 20,000 in capacity (Matheson, 2008). The National Football League’s (NFL) ProBowl has been predicted to attract nearly 50,000 visitors (Baumann and Matheson, 2016) and the 
NFL Super Bowl typically claims of tourist flows of 100,000 to 125,000 with some predicting that the 2014 game would attract up to 400,000 visitors to the New York City metropolitan area. (Prieto, 2014)

Of course, the expenses associated with hosting an event like the FIFA World Cup or the Olympics are quite large, and the majority of these costs are typically borne by the host country. Regarding infrastructure, FIFA requires host countries to have between eight and 12 stadiums capable of seating at least 40,000 spectators, and one of these stadiums must have at 80,000 capacity for the opening and final games. Olympiads require playing facilities for multiple sports, housing for 15,000 athletes and officials, and a minimum of 40,000 hotel rooms available for spectators. Despite being one of the most popular tourist destinations in South America, Rio de Janeiro still required the construction of over 15,000 new hotel rooms for the 2016 Summer Games (Baade and Matheson, 2016). The 2010 FIFA World Cup produced \$3.9 billion in expenses paid by South Africa, including at least $\$ 1.3$ billion in stadium construction costs (Voigt, 2010). As noted previously, Brazil’s 2014 FIFA World Cup carried a price tag estimated at $\$ 15$ billion, including at least $\$ 3.6$ billion in total spending on 12 new or refurbished stadiums.

Economists are typically skeptical that mega-events can generate sufficient economic benefits to cover the costs of hosting these tournaments (see Baade and Matheson, 2016, or Coates and Humphreys, 2008, among others). First, tourism estimates made prior to the event, especially if they are published by organizations with a vested interest, may be exaggerated in order to increase the amount of public subsidies. Second, if an event draws a primarily local audience, then spending at the event does not represent new money to the economy but rather a reallocation within the local area. Third, not all tourism spending stays in the local economy, particularly for expenditures on goods and services provided by multinational corporations. 
These leakages reduce the multiplier effect and thereby decrease the amount of economic impact generated by the event (Matheson, 2009).

A fourth issue is "crowding out", which occurs when the congestion of a mega-event dissuades other tourism or business travel to the host region. It is possible that this displacement effect may be severe, especially if the event is held during a high tourist season when hotel rooms are typically full. The UK Office for National Statistics (2015) reported that the number of international visitors to the country during the 2012 Summer Olympics fell to 6.174 million visitors compared to 6.568 million the year before, and some popular shows in London's theater district shut down during the Games. Similarly, Beijing similarly reported a 30 percent drop in international visitors and a 39 percent drop in hotel occupancy during the month of the 2008 Summer Olympics compared to the previous year. Utah ski resorts noted a 9.9 percent fall in attendance during the 2002 Salt Lake City Winter Olympics and a drop in taxable sales collections at these locations compared to the previous year (Zimbalist, 2015; Baade, Baumann, and Matheson, 2010). Taxable sales and skier visits rebounded the following season clearly implicating the Olympics in the one-time drop.

While there is a clear relationship, it must be noted that there is not a one to one connection between the number of tourists to an event and the event's economic impact. Often visitors to mega-sporting events are considered to be wealthier than the average tourist. Only the well-heeled, it is thought, can afford the steep ticket prices and costly accommodations that accompany a major event. For example, the average ticket price on secondary markets for Super Bowl tickets routinely exceed $\$ 2,500$, and even the cheapest ticket available to foreigners for the 2018 World Cup in Russia is \$105. (Seatgeek, 2017; Boehm, 2016) If sports tourists are wealthier, then a major event may cause overall tourism spending to rise even if there is not a net 
increase in the number of tourists. Heller and Stephenson's (2017) analysis of hotel receipts during mega-events finds that the vast majority of the increase in accommodation revenue during the Super Bowl occurs due to an increase in spending per person rather than an increase in the number of visitors. On the other hand, certain sports teams may have die-hard fans with bigger hearts than wallets. Anecdotally, a large number of Latin American visitors to Brazil during the World Cup spent their time sleeping on beaches rather than in luxury hotels. (Zimbalist, 2015). If this type of tourist made up a majority of the increase in visitors to the country during the World Cup, a significant increase in tourism may not result in a proportionally large increase in visitor spending. This analysis differentiates arrivals by air and ground in an attempt to address this issue.

Several academic studies have examined tourism inflows and visitor spending at FIFA World Cups. In general, the research finds, at best, modest impacts from hosting. Hagn and Maennig (2008) argue that the 1974 FIFA World Cup in Germany "was not able to generate any medium to long-term employment effects that were significantly different from zero”. Baade and Matheson (2004) estimate that host cities of the 1994 FIFA World Cup in the United States experienced a cumulative loss of at least $\$ 5.5$ billion. Feddersen, Grötzinger, and Maennig (2009) could not statistically identify any positive employment or income effects after the construction of stadiums for the 2006 FIFA World Cup in Germany. Allmers and Maennig (2009) examine overnight hotel stays and national tourism income and find no identifiable impact in either category in France during the 1998 FIFA World Cup. However, the same study estimates the 2006 FIFA World Cup in Germany produced an increase of approximately 700,000 additional hotel nights sold to foreigners and an additional 600 to 700 million euros (US\$ 830 to 970 million) in net national tourism income. 
In the research closest in nature to the analysis performed here, Du Plessis and Maennig (2011) and Peeters, Matheson and Szymanski (2014) both examine monthly tourist arrivals into South Africa with a focus on the 2010 FIFA World Cup. Both studies find that the country experienced an increase in tourism during the months of the tournament, but the net increase in tourist arrivals (40,000-80,000 in Du Plessis and Maennig, 2011, and 220,000 in Peeters, et al., 2014) were a fraction of the levels claimed by event organizers prior to the competition. Finally, Sterken (2006) analyzes FIFA World Cups from 1974 to 2004 and finds the event produces no discernable impact on per capita gross domestic product in the host country.

Other analyses of tourism effects from hosting large sporting events find similarly small effects. Baumann, Matheson, and Muroi (2009) and Baumann and Matheson (2016) examine visitor arrival data in Hawaii around the NFL Pro Bowl and Honolulu Marathon. These articles conclude that the net increase in the number of visitors to the state was less than half of the number of visiting spectators and participants at these events. Fourie and Santana-Gallego (2011) use a gravity model of annual bilateral tourism for 200 countries between 1995 and 2006. They find that, on average, an international mega-event increases tourist arrivals by roughly eight percent in the year of the event, but the results vary widely. The Summer Olympics, FIFA World Cup, and Cricket World Cup had the largest positive impacts on tourism while the Winter Olympics and Rugby World Cup were associated with reductions in annual tourist numbers.

\section{Data}

Monthly arrival data by foreigners into Brazil are from Anuário Estatístico, which is administered by the country’s Ministério do Turismo. Arrival data are available by land, air, and water and in aggregate, by the country of origin of the traveler. In practice, the number of 
arrivals by water is very small, so the terms "non-air arrivals” and "land arrivals” may be used roughly interchangeably. These data are available monthly from January 2003 to December 2015.

The quality of any type of economic data is always subject to question especially given the endemic corruption that is known to permeate the Brazilian government. That being said, tourism data has some distinct advantages over other types of economic data that makes it useful for estimating economic impact. Its primary advantage is the ease of collection which likely reduces measurement error. The data simply requires the tabulation of foreigners entering in to the country, and Brazil has a reasonably limited number of entry points. Visitors fill out a simple customs declaration upon arrival and these forms contain all of the information necessary to capture the required data. This is a far easy task than collecting data from either thousands of individual firms or millions of consumers about a wide variety of products. Furthermore, very few business transactions record the national origin of the purchaser making it difficult to disentangle purchases by visitors from those made by locals. Finally, visitor data is not subject to many of the types of underreporting or manipulation that other data sources face. Businesses have a financial incentive to underreport revenues and individuals have the inclination to underreport income in order to avoid taxes. Data collected from visitor surveys is subject to a wide array of biases well known in the literature (see Diamond and Hausman (1994) for a nice discussion). Visitors arriving at an entry point are unable to conceal their presence and generally have little reason or little ability to falsify their national origin. Of course, one can never rule out outright fraud on the part of the government agencies themselves, but among any governmental data source, international arrivals are likely to have among the highest degrees of accuracy, especially in a country that is fairly geographically isolated from most other nations. 
Table 1 provides summary statistics for several versions of the arrival data available from Anuário Estatístico.

Table 1: Mean Arrivals into Brazil (Standard Deviations in Parentheses)

\begin{tabular}{|c|c|c|c|}
\hline & All Travel & Airplane Travel & Percent by Airplane \\
\hline Total & 442,057 & 316,749 & $74.2 \%$ \\
& $(148,546)$ & $(72,414)$ & $(9.3)$ \\
\hline U.S.A. & 54,285 & 51,576 & $95.1 \%$ \\
& $(12,658)$ & $(11,928)$ & $(2.8)$ \\
\hline Argentina & 108,870 & 48,282 & $52.2 \%$ \\
& $(84,877)$ & $(23,090)$ & $(13.1)$ \\
\hline Uruguay & 21,082 & 5,837 & $31.4 \%$ \\
& $(10,353)$ & $(2,467)$ & $(13.4)$ \\
\hline Germany & 21,444 & 18,889 & $88.6 \%$ \\
& $(5,873)$ & $(4,903)$ & $(5.0)$ \\
\hline Belgium & 2,729 & 2,452 & $89.8 \%$ \\
& $(887)$ & $(873)$ & $(11.3)$ \\
\hline
\end{tabular}

Brazil attracts an average of 442,057 foreign visitors each month, and Argentina and the United States provide the first and second largest number of foreign visitors to Brazil, respectively. Not surprisingly, the distance to Brazil is correlated to both the number of annual visits as well as the likelihood of arriving by plane. For example, neighboring Uruguay sends roughly as many annual visitors as the much more populous Germany, but German tourists are significantly more likely to travel by air. This is an important distinction as it is reasonable to conclude that travelers arriving by air are likely to be wealthier than those forced to make the 1,500 mile, 28 hour trip from Montevideo by car or bus. Note that arrival data counts the nationality of the visitor rather than the country from which the tourist is arriving. For example, a German citizen who flies to Argentina and then drives into Brazil would be counted as a German visitor arriving by car. 


\section{Empirical Models}

We begin with a panel estimation that evaluates the FIFA World Cup’s impact on arrivals in Brazil. In order to evaluate how outcomes on the field can lead to large fluctuations in tourism, we begin with a difference-in-difference approach. Due to the length of the tournament, we establish two treatment groups: countries with national teams in the group stage and the knockout round. The group stage, which ran from June 12 to June 26 2014, includes three games for each of the tournament's 32 teams. Half of these teams advance to a single-elimination tournament known as the knockout round, which ran from June 28 to July 14 2014. Given this timing, we formulate the following difference-in-difference in equation (1). Rather than controlling for only group stage and knockout round participant countries, we use a fixed effect term for all origin countries.

$$
\begin{aligned}
& \operatorname{arrivals}_{c t}=\alpha+\beta_{1} \text { june2014 } c t+\beta_{2} \text { july2014 } c t \\
& +\delta_{1} \text { june } 2014_{c t} * \text { group }_{c t}+\delta_{2}{\text { july } 2014_{c t} * \text { knockout }_{c t}} \\
& +\sum_{m} \phi_{m} m_{t}+\sum_{y} \phi_{y} y_{t}+\lambda_{c}+\varepsilon_{c t}
\end{aligned}
$$

Equation (1) can be written for either of our dependent variables, specifically all arrivals and arrivals by plane. The parameters $\beta_{1}$ and $\beta_{2}$ measure the increase in tourism from any country during the FIFA World Cup months of June and July 2014. The parameters $\delta_{1}$ and $\delta_{2}$ measure the treatment effect, or the increase in tourism from countries with teams in the group stage and knockout round. One complication is that Anuário Estatístico provides country of origin data for only 53 countries, and the remaining countries are placed into continent-specific “other countries” categories that aggregates visitors from typically small contributors to 
Brazilian tourism. We omit these from our data set, though our results are not substantially affected by their inclusion. Because of this distinction, not all of the national teams in the group stage and knockout round have tourism data. Specifically, our data includes tourism data from 23 of the possible 31 foreign countries in the group stage and 14 of the 15 foreign countries in the knockout round. ${ }^{4}$ We also include monthly dummy variables $m_{t}$ to control for seasonal variations in tourism and yearly dummy variables $y_{t}$ to control for worldwide macroeconomic trends that may impact tourism. These are particularly important since the sample frame envelops the worldwide economic slowdown during the late 2000s. Because of the monthly and yearly dummy variables, time trends do not substantially impact the estimates and are omitted.

Figure 1 illustrates all tourist arrivals into Brazil for the portion of our data between January 2010 and December 2015. The regular spikes in the data indicate seasonal fluctuations in Brazilian arrivals, which peak during the southern hemisphere summer months December and January. The largest peak occurs in mid-2014, which is the timing of the FIFA World Cup in Brazil. The seasonal peaks before and after the World Cup are also interesting. The summer prior to the FIFA World Cup had a below average seasonal peak, which suggests some degree of time switching behavior from those postponing a trip to Brazil for the tournament. In comparison, the summer after the FIFA World Cup had an above average peak in international visitors, which may be caused by the promotional benefits of hosting. Roughly 74 percent of arrivals to Brazil travel by plane, though it is clear from Figure 1 that this percentage varies by season. In general, most of the spike in arrivals that occurs during summer does not happen by airplane.

4 Excluding Brazil, whose national team participated in both the group stage and knockout round, there are 31 foreign countries in the group stage and 15 in the knockout round at the 2014 FIFA World Cup. We have tourism data for all group stage participants except Algeria, Bosnia and Herzegovina, Cameroon, Croatia, Ghana, Iran, and Ivory Coast. We have tourism data for all knockout round participants except Algeria. 
Figure 1: Monthly Arrivals into Brazil; any Country of Origin

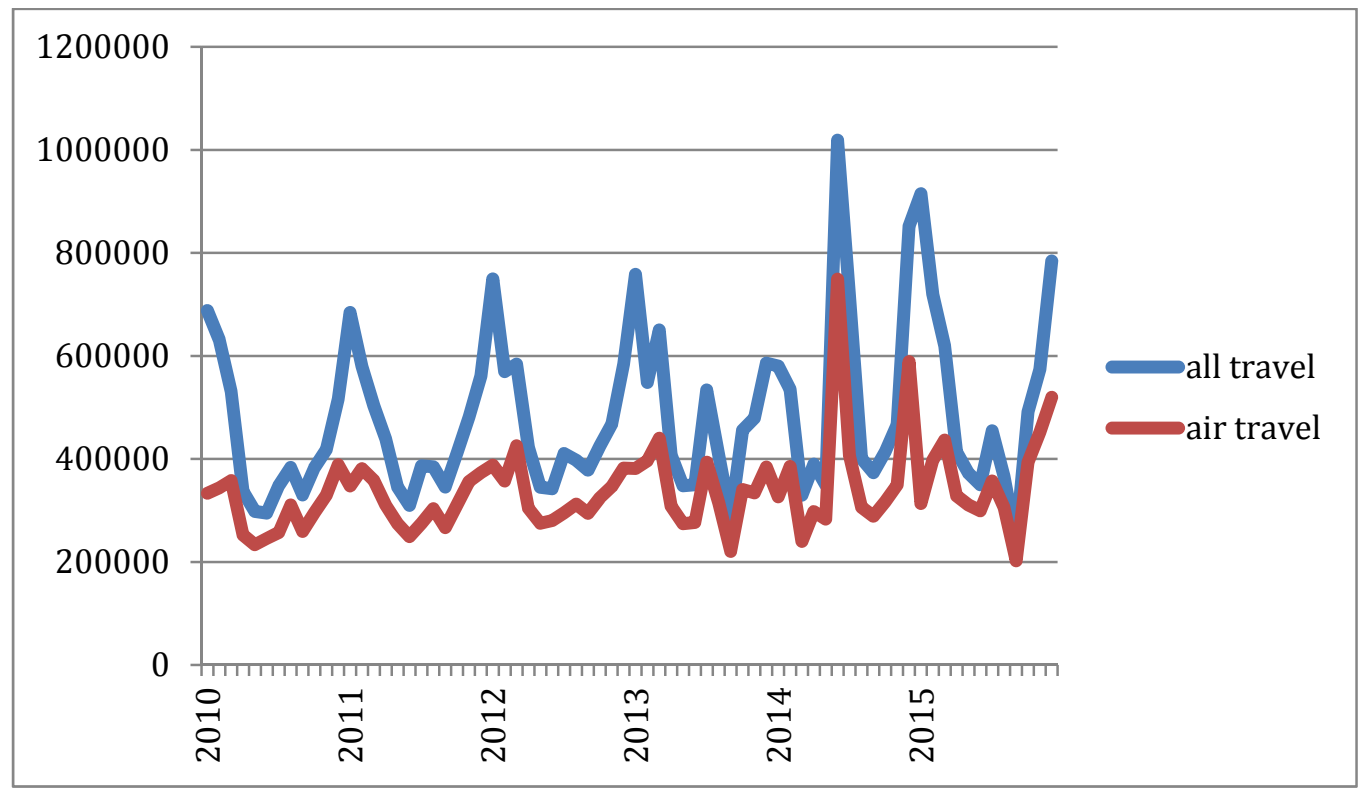

Before estimating equation (1), we pause to check whether the data are stationary. We employ the standard tests - augmented Dickey-Fuller, Phillips-Perron, and Kwiatowski-PerronSchmidt-Shin - to test for the presence of a unit root. Because these tests are intended for crosssections of time series data (in our sample, arrivals from one country) and not panels, we present the results for the aggregated data of all international tourism into Brazil over the sample frame. Though not presented for brevity, the stationary tests for cross-sections of each individual country are largely similar and available upon request. We use the Ng-Perron approach to find the optimal lag structure for these tests. This approach suggests 11 lags in both the all arrivals and air arrivals specifications. The following tests do not contain time trends because they do not substantially change the outcomes. The results are mixed for the dependent variable in levels. In comparison, the first difference of each dependent variable uniformly rejects the presence of a unit root. Table 2 presents these test results.

Table 2: Unit Root Tests; All Foreign Tourism into Brazil 


\begin{tabular}{|c|c|c|c|}
\hline & $\begin{array}{c}\text { Augmented Dickey- } \\
\text { Fuller }\end{array}$ & Philips-Perron & $\begin{array}{c}\text { Kwiatowski-Perron- } \\
\text { Schmidt-Shin }\end{array}$ \\
\hline all arrivals & $\begin{array}{c}-1.731 \\
(p=0.4152)\end{array}$ & $\begin{array}{c}-5.010 \\
(p<0.001)\end{array}$ & $\begin{array}{c}0.868 \\
(p<0.01)\end{array}$ \\
\hline air arrivals & -1.904 & -7.389 & 0.752 \\
& $(p=0.3303)$ & $(p<0.001)$ & 0.263 \\
\hline all arrivals & -7.225 & -20.553 & $(p>0.1)$ \\
\hline air arrivals & $(p<0.001)$ & $(p<0.001)$ & 0.204 \\
& -8.124 & $(p<0.049$ & $0.1)$ \\
\hline
\end{tabular}

Note: Each cell contains the test statistic and p-value. For augmented Dickey-Fuller and Phillips-Perron, the null hypothesis is the presence of a unit root. For Kwiatowski-PerronSchmidt-Shin, the null hypothesis is a stationary time series. Each test uses lag terms from one to 11.

Because the unit root tests have mixed results, we present two estimations of equation (1). Table 3 presents the least squares estimation of equation (1) where the dependent variable is measured in levels. We cluster the standard errors at the country-of-origin level in order to mitigate heteroskedasticity. In essence, this estimates separate error variances for each country of origin. Due to the variation in foreign visitors during the seasonal peaks before and after the 2014 FIFA World Cup seen in Figure 1, we also include dummy variables for the Brazilian summers of December 2013 through February 2014 and December 2014 through February 2015. Though not presented for brevity and available upon request, all estimations include dummy variables for each year and month.

Table 3: Difference-in-Difference Estimations

\begin{tabular}{|c|c|c|c|c|}
\hline Dependent Variable & all arrivals ${ }_{t}$ & $\operatorname{air}_{\text {arrivals }}$ & $\Delta$ all arrivals $t_{t}$ & $\Delta$ air arrivals $t_{t}$ \\
\hline June 2014 dummy & $\begin{array}{c}4,381 \\
(p=0.006)\end{array}$ & $\begin{array}{c}2,811 \\
(p<0.001)\end{array}$ & $\begin{array}{c}3,388 \\
(p=0.001)\end{array}$ & $\begin{array}{c}2,557 \\
(p<0.001)\end{array}$ \\
\hline July 2014 dummy & $\begin{array}{c}1,409 \\
(p=0.067)\end{array}$ & $\begin{array}{c}634 \\
(p=0.046)\end{array}$ & $\begin{array}{c}2,052 \\
(p=0.021)\end{array}$ & $\begin{array}{c}1,398 \\
(p=0.021)\end{array}$ \\
\hline $\begin{array}{c}\text { June } 2014 * \text { Group } \\
\text { Stage Team }\end{array}$ & $\begin{array}{c}19,463 \\
(p=0.007)\end{array}$ & $\begin{array}{c}12,880 \\
(p=0.002)\end{array}$ & $\begin{array}{c}20,590 \\
(p=0.006)\end{array}$ & $\begin{array}{c}13,504 \\
(p<0.001)\end{array}$ \\
\hline $\begin{array}{c}\text { July } 2014 * \text { Knockout } \\
\text { Round Team }\end{array}$ & $\begin{array}{c}17,114 \\
(p=0.289)\end{array}$ & $\begin{array}{c}3,300 \\
(p=0.089)\end{array}$ & $\begin{array}{c}13,023 \\
(p=0.388)\end{array}$ & $\begin{array}{c}1,012 \\
(p=0.723)\end{array}$ \\
\hline
\end{tabular}




\begin{tabular}{|c|c|c|c|c|}
\hline Summer 2013/2014 & $\begin{array}{c}-1,511 \\
(p=0.111)\end{array}$ & $\begin{array}{c}-709 \\
(p=0.001)\end{array}$ & $\begin{array}{c}-1,412 \\
(p=0.082)\end{array}$ & $\begin{array}{c}-426 \\
(p<0.001)\end{array}$ \\
\hline Summer 2014/2015 & $\begin{array}{c}3,276 \\
(p=0.228)\end{array}$ & $\begin{array}{c}348 \\
(p=0.106)\end{array}$ & $\begin{array}{c}245 \\
(p=0.690)\end{array}$ & $\begin{array}{c}-260 \\
(p=0.009)\end{array}$ \\
\hline
\end{tabular}

It is clear from the estimates at Table 3 that the 2014 FIFA World Cup attracted tourists from all over the world. For countries without a national team in 2014 FIFA World Cup, we estimate that the event attracted between 3,388 and 4,381 visitors per country during June. We also estimate a positive bump in international tourism during July 2014. Countries with a national team in the group stage attracted an additional 20,000 visitors per country in June. Further, countries with national teams in the knockout round brought an additional 13,000 to 17,000 visitors to Brazil, though these estimates are not statistically significant. It is also notable that a large percentage of the July 2014 foreign tourism gains did not arrive by airplane. While foreign net air arrivals during July 2014 are positive, their estimates are smaller and less precise compared to the estimations that analyze all arrivals to Brazil. We also find some evidence of time switching tourism behavior. The summer prior to the 2014 FIFA World Cup had a negative impact on net foreign tourism, though we cannot be certain this was caused by tourists delaying a trip to Brazil for the upcoming 2014 FIFA World Cup. In addition, the summer following the 2014 FIFA World Cup produces a net increase in foreign tourism, which may be caused by the promotional benefits of the event. We conclude that the draw of the home country's national team is a powerful force in FIFA World Cup international tourism, and it is important to note that all but two of the group stage participants (the host country and previous FIFA World Cup champion) are not known at the time when countries bid to host the event.

We now turn to estimations for specific countries-of-origin in order to analyze how 
exogenous outcomes on the field impact international visitors. Because our estimations now use cross section data, we omit the group stage, knockout round, and fixed effect controls from equation (1) due to perfect collinearity. Each row of Table 4 represents two estimations of equation (1): the first set of estimates uses all arrivals to Brazil while the second set uses only airplane arrivals. Since Anuário Estatístico provides arrival data for 53 countries, equation (1) can be estimated for each country of origin. For brevity, Table 4 only presents estimations for total foreign arrivals into Brazil and a subset of countries whose national team participated in at least the group stage. Estimations for each country of origin are available upon request.

Table 4: Least Squares Estimations; Dependent Variable in Levels

\begin{tabular}{|c|c|c|c|c|c|}
\cline { 3 - 6 } \multicolumn{2}{c|}{} & \multicolumn{2}{c|}{ All } & Arrivals & \multicolumn{2}{c|}{ Airplane } & Arrivals \\
\hline $\begin{array}{c}\text { Country } \\
\text { of Origin }\end{array}$ & $\begin{array}{c}\text { Made } \\
\text { Knockout? }\end{array}$ & $\begin{array}{c}\text { World Cup } \\
\text { June 2014 }\end{array}$ & $\begin{array}{c}\text { World Cup } \\
\text { July 2014 }\end{array}$ & $\begin{array}{c}\text { World Cup } \\
\text { June 2014 }\end{array}$ & $\begin{array}{c}\text { World Cup } \\
\text { July 2014 }\end{array}$ \\
\hline All Countries & N/A & $\begin{array}{c}696,770 \\
(p<0.001)\end{array}$ & $\begin{array}{c}318,835 \\
(p<0.001)\end{array}$ & $\begin{array}{c}474,327 \\
(p<0.001)\end{array}$ & $\begin{array}{c}92,527 \\
(p=0.003)\end{array}$ \\
\hline U.S.A. & Yes & $\begin{array}{c}85,073 \\
(p<0.001)\end{array}$ & $\begin{array}{c}12,686 \\
(p=0.008)\end{array}$ & $\begin{array}{c}83,900 \\
(p<0.001)\end{array}$ & $\begin{array}{c}12,221 \\
(p=0.007)\end{array}$ \\
\hline Argentina & Yes & $\begin{array}{c}204,772 \\
(p<0.001)\end{array}$ & $\begin{array}{c}257,633 \\
(p<0.001)\end{array}$ & $\begin{array}{c}34,555 \\
(p<0.001)\end{array}$ & $\begin{array}{c}25,838 \\
(p<0.001)\end{array}$ \\
\hline Chile & Yes & $\begin{array}{c}59,618 \\
(p<0.001)\end{array}$ & $\begin{array}{c}-6,333 \\
(p=0.040)\end{array}$ & $\begin{array}{c}28,852 \\
(p<0.001)\end{array}$ & $\begin{array}{c}-5,678 \\
(p=0.041)\end{array}$ \\
\hline Colombia & Yes & $\begin{array}{c}38,823 \\
(p<0.001)\end{array}$ & $\begin{array}{c}1,482 \\
(p=0.203)\end{array}$ & $\begin{array}{c}34,509 \\
(p<0.001)\end{array}$ & $\begin{array}{c}1,711 \\
(p=0.072)\end{array}$ \\
\hline Ecuador & No & $\begin{array}{c}13,853 \\
(p<0.001)\end{array}$ & $\begin{array}{c}-191 \\
(p=0.650)\end{array}$ & $\begin{array}{c}13,010 \\
(p<0.001)\end{array}$ & $\begin{array}{c}12 \\
(p=0.978)\end{array}$ \\
\hline Uruguay & No & $\begin{array}{c}18,414 \\
(p<0.001)\end{array}$ & $\begin{array}{c}815 \\
(p=0.739)\end{array}$ & $\begin{array}{c}7,182 \\
(p<0.001)\end{array}$ & $\begin{array}{c}-1,821 \\
(p=0.035)\end{array}$ \\
\hline Germany & Yes & $\begin{array}{c}20,774 \\
(p<0.001)\end{array}$ & $\begin{array}{c}8,074 \\
(p<0.001)\end{array}$ & $\begin{array}{c}20,605 \\
(p<0.001)\end{array}$ & $\begin{array}{c}8,422 \\
(p<0.001)\end{array}$ \\
\hline Belgium & No & 7,981 & 63 & 8,036 & 56 \\
\hline
\end{tabular}




\begin{tabular}{|l|l|l|l|l|l|}
\hline & & $(p<0.001)$ & $(p=0.822)$ & $(p<0.001)$ & $(p=0.830)$ \\
\hline
\end{tabular}

Note: Each estimation uses Huber/White robust standard errors.

The main result from Table 4 is that the FIFA World Cup increased net foreign arrivals into Brazil by about one million people over June and July 2014, and a little more than half of which arrived by airplane. The majority of this increase occurs in June, which is also when all 32 teams are still competing.

Of all countries of origin (including those not presented at Table 4), Argentina provided the most net arrivals to Brazil during the FIFA World Cup. This is likely driven by Argentina's population, the success of its national team, and the country's proximity to Brazil. We estimate that over 200,000 additional Argentines visited Brazil in June 2014, and this number jumped to over 250,000 in July 2014. In fact, we estimate that over 80 percent of the rise in net tourism during July comes from Argentina. Further, a large majority of Argentine net arrivals did not enter Brazil by airplane. Less than 17 percent arrived by plane in June 2014 and only ten percent arrived by plane in July 2014. We will explore this further in the next section, but it is important to once again note that not all tourists are created equal when it comes to their impact on the Brazilian economy. The fact that the World Cup was associated with large increases in air arrivals from rich countries such as the United States and Germany bodes well for the subsequent spending in the country after their arrival. This is not necessarily so with the hundreds of thousands of Argentinians who arrived by car. Those visitors without the means to avoid the arduous trip by land from Argentina to the various Brazilian host cities are unlikely to have spent vast sums of money while in the country.

As the results from the unit root testing are somewhat ambiguous, Table 5 estimates uses the first difference of the dependent variable. As with Table 4, month and year are included in all 
estimations and only a subset of origin locations are presented but all results are available upon request.

Table 5: Least Squares Estimations; Dependent Variable in Differences

\begin{tabular}{|c|c|c|c|c|c|}
\hline & & All & Arrivals & Airplane & Arrivals \\
\hline $\begin{array}{c}\text { Country } \\
\text { of Origin }\end{array}$ & $\begin{array}{c}\text { Made } \\
\text { Knockout? }\end{array}$ & $\begin{array}{l}\text { World Cup } \\
\text { June } 2014\end{array}$ & $\begin{array}{c}\text { World Cup } \\
\text { July } 2014\end{array}$ & $\begin{array}{l}\text { World Cup } \\
\text { June } 2014\end{array}$ & $\begin{array}{l}\text { World Cup } \\
\text { July } 2014\end{array}$ \\
\hline All Countries & N/A & $\begin{array}{c}676,946 \\
(p<0.001)\end{array}$ & $\begin{array}{c}296,652 \\
(p<0.001)\end{array}$ & $\begin{array}{c}472,581 \\
(p<0.001)\end{array}$ & $\begin{array}{c}94,867 \\
(p<0.001)\end{array}$ \\
\hline U.S.A. & Yes & $\begin{array}{c}81,444 \\
(p<0.001)\end{array}$ & $\begin{array}{c}9,300 \\
(p=0.004)\end{array}$ & $\begin{array}{c}80,649 \\
(p<0.001)\end{array}$ & $\begin{array}{c}9,251 \\
(p=0.003)\end{array}$ \\
\hline Argentina & Yes & $\begin{array}{c}192,981 \\
(p<0.001)\end{array}$ & $\begin{array}{c}241,513 \\
(p<0.001)\end{array}$ & $\begin{array}{c}41,076 \\
(p<0.001)\end{array}$ & $\begin{array}{c}32,367 \\
(p<0.001)\end{array}$ \\
\hline Chile & Yes & $\begin{array}{c}62,438 \\
(p<0.001)\end{array}$ & $\begin{array}{c}-4,381 \\
(p<0.001)\end{array}$ & $\begin{array}{c}32,691 \\
(p<0.001)\end{array}$ & $\begin{array}{c}-2,079 \\
(p=0.140)\end{array}$ \\
\hline Colombia & Yes & $\begin{array}{c}38,641 \\
(p<0.001)\end{array}$ & $\begin{array}{c}1,390 \\
(p=0.044)\end{array}$ & $\begin{array}{c}34,409 \\
(p<0.001)\end{array}$ & $\begin{array}{c}1,530 \\
(p=0.001)\end{array}$ \\
\hline Ecuador & No & $\begin{array}{c}13,897 \\
(p<0.001)\end{array}$ & $\begin{array}{c}-295 \\
(p=0.258)\end{array}$ & $\begin{array}{c}13,288 \\
(p<0.001)\end{array}$ & $\begin{array}{c}422 \\
(p=0.535)\end{array}$ \\
\hline Uruguay & No & $\begin{array}{c}15,771 \\
(p<0.001)\end{array}$ & $\begin{array}{c}-2,502 \\
(p<0.001)\end{array}$ & $\begin{array}{c}7,874 \\
(p<0.001)\end{array}$ & $\begin{array}{c}-1,536 \\
(p<0.001)\end{array}$ \\
\hline Germany & Yes & $\begin{array}{c}19,721 \\
(p<0.001)\end{array}$ & $\begin{array}{c}6,755 \\
(p<0.001)\end{array}$ & $\begin{array}{c}19,291 \\
(p<0.001)\end{array}$ & $\begin{array}{c}7,040 \\
(p<0.001)\end{array}$ \\
\hline Belgium & Yes & $\begin{array}{c}8,044 \\
(p<0.001)\end{array}$ & $\begin{array}{c}239 \\
(p=0.327)\end{array}$ & $\begin{array}{c}7,948 \\
(p<0.001)\end{array}$ & $\begin{array}{c}136 \\
(p=0.650)\end{array}$ \\
\hline
\end{tabular}

Note: Each estimation uses Huber/White robust standard errors.

The results in Table 5 are largely similar to Table 4. In this estimation, the total increase in net arrivals is about 973,000 compared to 1.015 million in Table 4. Argentina remains the largest arrival country, and also the only group of visitors to increase net arrivals in July compared to June.

Counterfactual: Belgium v. Argentina, July 5, 2014

While one million net visitors to Brazil is a substantial influx of tourism, it is important to note that outcomes on the field play a significant role in FIFA World Cup tourism. On July 5 2014, Argentina eliminated Belgium by a score of one to zero. The following estimates the 
impact on net arrivals had Belgium won instead in order to illustrate how on-field results influence net tourism.

Figures 2 and 3 display net arrivals into Brazil during the FIFA World Cup months June and July 2014, respectively, using estimates from Table 3 and other estimations omitted for brevity. In June 2014, we estimate net arrivals into Brazil increased by 696,770, which we break into seven origin locations. The pie chart for July 2014 is similarly constructed but with five origin locations.

Figure 2: Estimated World Cup Net Tourism, June 2014

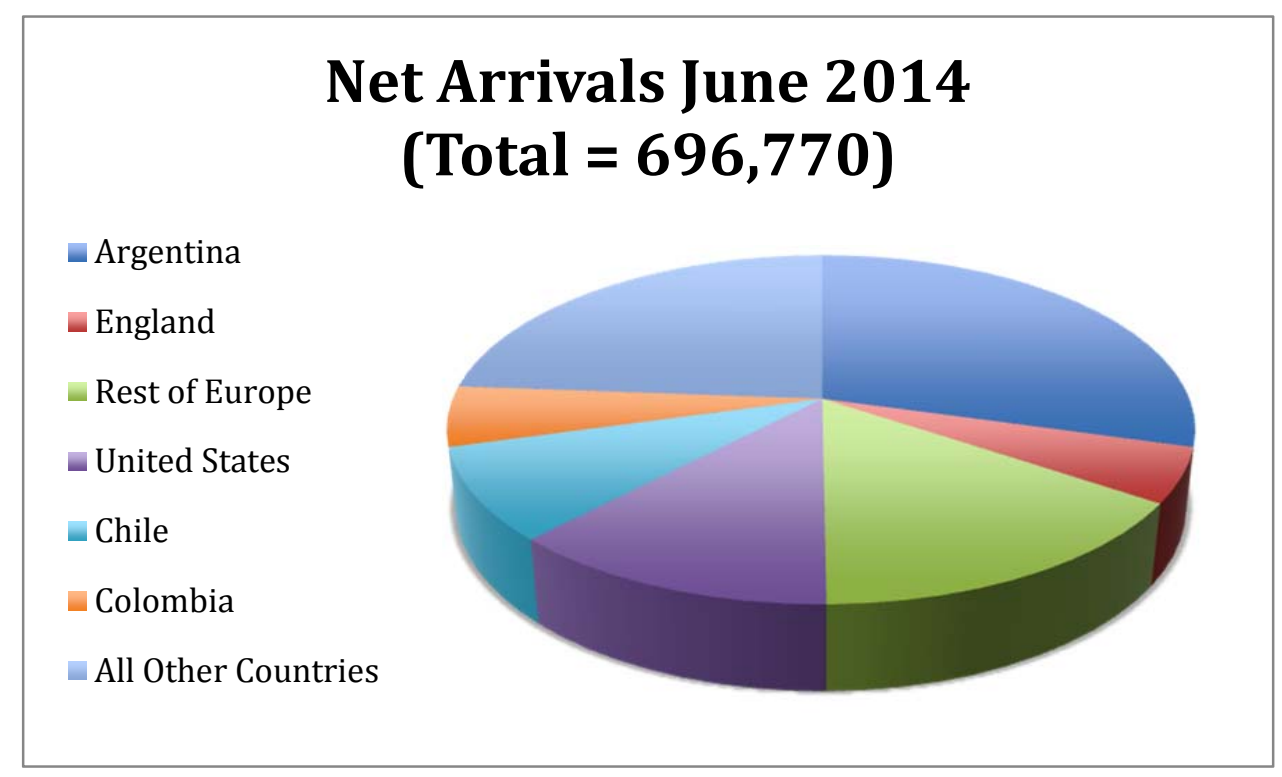

Figure 3: Estimated World Cup Net Tourism, July 2014 


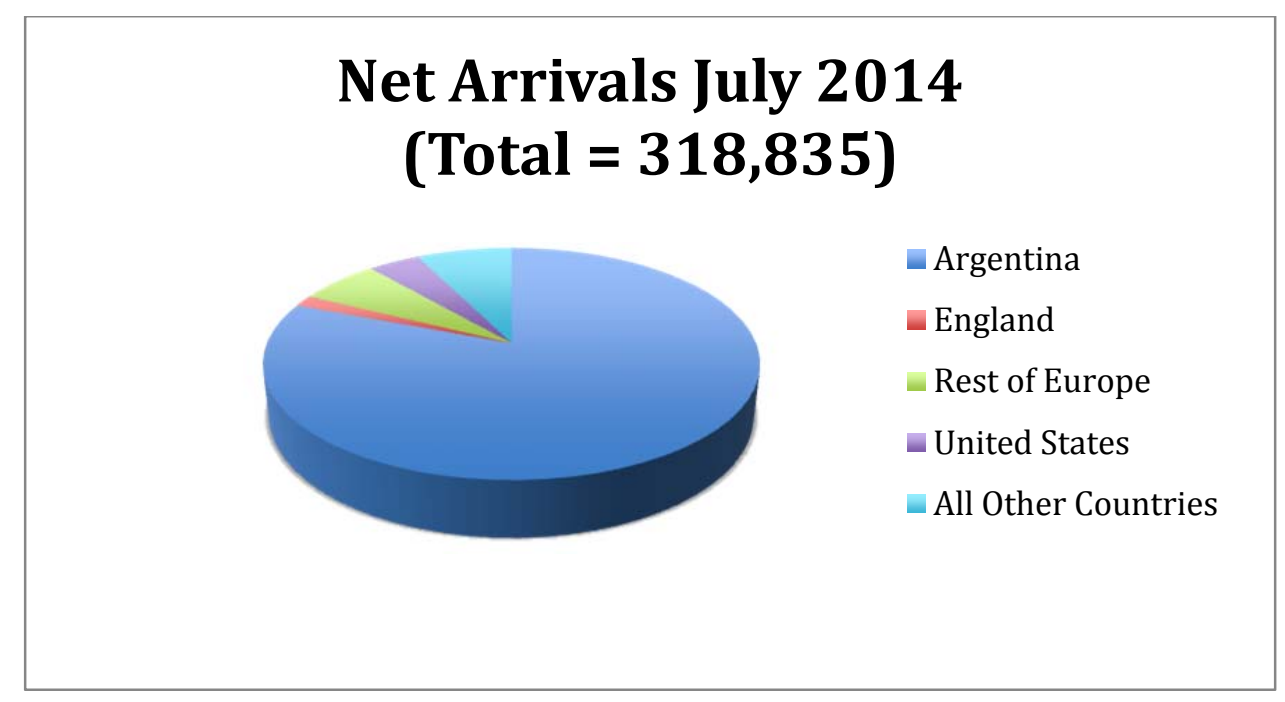

There are two notable aspects of Figures 2 and 3. First, July net arrivals are less than half of net arrivals in June. This is not surprising given that half of the teams are eliminated by the first week of July. Second, the percentage of net arrivals from Argentina increased substantially between June and July: roughly 29.4 percent in June compared to over 80 percent in July.

Using these results, we estimate net arrivals in Brazil had Argentina lost to Belgium. Rather than assuming zero Argentine net arrivals if their national team lost to Belgium, we use its neighbor Uruguay, whose national team was eliminated by a loss in the knockout round to Colombia on June 29, as a guide. Similarly, we use German net arrivals to estimate the increase in Belgian net arrivals had Belgium beat Argentina. The German national team would ultimately win the 2014 FIFA World Cup, and this exercise assumes its participation deep into the knockout round spurred the increase in German net arrivals.

Based on the estimates from Table 4, July had roughly 38.9 percent of the German net arrivals compared to June. Assuming the same percentage had Belgium advanced further in the tournament, this translates to an increase in net arrivals of about 3,100 Belgians. We use a similar comparison to estimate the loss in net tourism from Argentina had its national team lost 
to Belgium. July net arrivals from Uruguay are roughly 4.4 percent of the June estimate. Assuming the same percentage, we estimate net arrivals from Argentina would be roughly 9,000 had its national team lost. Comparing these outcomes suggests that the impact of Argentina beating Belgium, which only happened by one goal, led to an increase in over 245,000 net arrivals. Given the overall increase in net tourism is roughly one million, this translates to onequarter of the net increase in Brazilian visitors during the 2014 FIFA World Cup. In essence, Brazil was fortunate that Argentina advanced deep into the tournament as it spurred a substantial amount of its FIFA World Cup tourism. Table 5 summarizes this information. 
Table 5: Counterfactual Estimation

\begin{tabular}{|c|c|c|c|}
\hline & $\begin{array}{c}\text { Observed July Net } \\
\text { Arrivals given } \\
\text { Argentina won }\end{array}$ & $\begin{array}{c}\text { Estimated July Net } \\
\text { Arrivals had } \\
\text { Belgium won }\end{array}$ & $\begin{array}{c}\text { Net Effect had } \\
\text { Belgium won }\end{array}$ \\
\hline Belgium & 63 & 3,101 & 3,038 \\
\hline Argentina & 257,632 & 9,063 & $+\underline{+248,569}$ \\
\cline { 3 - 4 }
\end{tabular}

While these comparisons are not perfect, the size of the impact is striking. It is clear from this exercise that a substantial amount of tourism is out of the control of FIFA World Cup planners. While other counterfactuals are possible, such as changing the outcome of a knockout round victory by Colombia over Uruguay, they are small in comparison to Argentina's advancement. We conclude that the uncertainty of on-the-field outcomes introduces a significant amount of statistical noise to any ex ante economic impact estimation.

\section{Conclusions}

We estimate that the 2014 FIFA World Cup attracted an additional one million visitors to Brazil over a two-month period. This is a substantial figure considering that the event occurred during the typically low-tourism winter months of Brazil. It is also notable that our estimates exceeded government predictions prior to the event. This is an improvement over the 2010 FIFA World Cup in South Africa, where the net increases in foreign arrivals during the tournament were between one quarter and one half of expectations leading up to the event.

We also identify a source of substantial variation in tourism: on-field results. Our estimates indicate that roughly a quarter of the net increase in tourism occurred because of 
Argentina's advancement to the final game. We interpret this finding as a cautionary example to any future hosts of the FIFA World Cup: ex ante estimates cannot incorporate on-field outcomes, and these outcomes have a significant impacts on tourism. Based on our findings, organizers of the 2018 FIFA World Cup in Russia should hope that European teams from populous countries, such as Germany, France, and England, advance deep in the tournament in order to maximize foreign tourism and therefore economic impact. Furthermore, the success of these countries would be doubly beneficial as they are likely to have relatively wealthy fans who would have the ability to spend more while in the country. The majority of Brazil's tourist windfall came by car or bus from Argentina, suggesting a lower economic impact than one might normally expect from this number of visitors.

It is also worth noting that the impact of on-field results varies across large sporting events. For example, it is hard to imagine that Olympic tourism is substantially influenced by the advancement of team or athlete to the medal round. However, for other events such as the Super Bowl or opening rounds of the NCAA Men’s Basketball Tournament, tourism is likely impacted by the proximity of the teams in the game. Nevertheless, despite the unexpectedly large increase in tourism due to the FIFA World Cup, this research offers another source of skepticism to any ex ante estimate of economic impact.

\section{REFERENCES}

Allmers, S., and Maennig, W. 2009. "Economic Impacts of the FIFA Soccer World Cups in France 1998, Germany 2006, and Outlook for South Africa 2010,” Eastern Economic 
Journal 35(4): 500-519.

Baade, R.A., and V.A. Matheson. 2004. "The quest for the cup: assessing the economic impact of the world cup." Regional Studies 38(4): 343-354.

Baade, R. and Matheson, V. 2016. "Going for the Gold: The Economics of the Olympics,” Journal of Economic Perspectives 30(2): 201-218.

Baade, R., Baumann, R. and Matheson, V. 2010. "Slippery slope: Assessing the economic impact of the 2002 Winter Olympic Games in Salt Lake City, Utah.” Region et Développment 31: 81-91.

Baumann, R. and Matheson, V. 2016. "Many Happy Returns? The Pro-Bowl, Mega-events, and Tourism in Hawaii,” Tourism Economics, forthcoming.

Baumann, R., Matheson, V. and Muroi, C. 2009. "Bowling in Hawaii: Examining the Effectiveness of Sports-Based Tourism Strategies,” Journal of Sports Economics 10 (1): 107-123.

Boehm, C. 2016. "FIFA announces ticket prices for 2018 World Cup, 2017 Confederations Cup,” https://www.mlssoccer.com/post/2016/07/11/fifa-announces-ticket-prices-2018world-cup-2017-confederations-cup, posted July 11, 2016.

Box, G. and Tiao, G. 1975. "Intervention Analysis with Applications to Economic and Environmental Problems,” Journal of the American Statistical Association 70: 70-79.

Coates, D. and Humphreys, B. 2008. "Do Economists Reach a Conclusion on Subsidies for Sports Franchises, Stadiums, and Mega-Events?” Econ Journal Watch 5(3): 294-315.

Deloitte. September 2008. "Potential Economic Impact of the Rugby World Cup on a Host Nation.” Staff report. 
Diamond, P. and Hausman, J. 1994. "Contingent Valuation: Is Some Number better than No Number?” Journal of Economic Perspectives, 8(4): 45-64.

Du Plessis, S. and Maennig, W. 2010. “The 2010 FIFA World Cup high frequency data economics: Effects on international tourism and awareness for South Africa," Development Southern Africa 28 (3): 349-365.

Feddersen, A., A.L. Grötzinger, and W. Maennig. 2009. "Investment in Stadia and Regional Economic Development-Evidence from FIFA World Cup 2006." International Journal of Sport Finance 4.4: 221-239.

FIFA. 2010. "Study reveals tourism impact in South Africa," http://www.fifa.com/worldcup/news/y=2010/m=12/news=study-reveals-tourism-impactsouth-africa-1347377.html, posted December 7, 2010.

Fourie, J. and Santana-Gallego, M. 2011. “The Impact of Mega-sport Events on Tourist Arrivals”, Tourism Management, 32: 1364-70.

Hagn, F., and W. Maennig. 2008. "Employment effects of the football World Cup 1974 in Germany." Labour Economics 15 (5): 1062-1075.

Heller, L. and Stephenson, E.F.. "If You Host It Will They Come? The Effect of the Super Bowl on Host City Hotel Occupancy,” Working Paper, April 2017.

Matheson, V. 2008. “Mega-Events: The Effect of the World's Biggest Sporting Events on Local, Regional, and National Economies," in The Business of Sports, Vol. 1,” D. Howard and B. Humphreys, eds., (Westport, CT: Praeger Publishers): 81-99.

Matheson, V. 2009. “Economic Multipliers and Mega-Event Analysis,” International Journal of Sport Finance 4(1): 63-70. 
Peeters, T., Matheson, V., and Szymanski, S. 2014. “Tourism and the 2010 World Cup: Lessons for Developing Countries,” Journal of African Economies 23(2): 290-320.

Prieto, B. 2014. “Super Bowl week get underway: NY/NJ to see some 400,000 tourists,” Denver Post, http://www.denverpost.com/2014/01/27/super-bowl-week-gets-underway-n-y-n-jto-see-some-400000-tourists/, posted January 27, 2014.

Rihlamvu, E. 2011. “2010 FIFA Soccer World Cup,” Africa Travel, http://www.africaata.org/sports.htm, accessed March 31, 2011.

Seatgeek. 2017. “Super Bowl 52,” https://seatgeek.com/events/super-bowl, accessed August 15, 2017.

Sterken, E. 2006. “Growth impact of major sporting events,” European Sport Management Quarterly 6(4): 375-389.

Szymanski, S. 2002. “The Economic Impact of the World Cup,” World Economics 3 (1): 169177.

The Week. 2012. "How many tourists are coming to London for the Olympics?” http://www.theweek.co.uk/olympics/london-2012/47177/how-many-tourists-are-cominglondon-olympics, posted May 30, 2012.

Utley, G. 2014. “IOC Predicts 480,000 Tourists in Rio for 2016 Olympics,” The Rio Times, http://riotimesonline.com/brazil-news/rio-business/ioc-predicts-480000-tourists-in-rio2016/, posted July 15, 2014.

Voigt, K. 2010. “Is there a World Cup economic bounce?” CNN.com, http://edition.cnn.com/2010/BUSINESS/06/11/business.bounce.world.cup/index.html, accessed March 31, 2011, posted June 11, 2010.

Zimbalist, A. 2015. Circus Maximus: The Economic Gamble Behind Hosting the Olympics and 
the World Cup, Brookings Institution Press. 